\title{
TUGAS REVIEW JURNAL MENGENAI SISTEM INFORMASI MANAGEMEN PEMERINTAHAN
}

\author{
ILMU PEMERINTAHAN
}

UNIVERSITAS HALU OLEO

KELOMPOK 4

MOHAMMAD ZAMZAM TISTAFTIYAN $\quad$ : C1B117174

POPY FEBRIANTI : C1B117204

RERI AIME FESTAHO : C1B117213

\section{Promosi Kuliner Jepang Melalui Media Social Sebagai Bentuk Diplomasi Publik : study facebook kedutaan besar jepang Indonesia}

Permasalahan yang diangkat dalam membahas jurnal ini yaitu tentang promosi kuliner Kedutaan Besar Jepang di Indonesia melalui media sosial Facebook sebagai bentuk diplomasi publik. Diplomasi publik dipahami sebagai upaya suatu negara dalam mempromosikan tujuan nasional dengan memengaruhi opini publik di negara lain dengan pelibatan tidak hanya negara sebagai aktor namun juga aktor non negara dalam hal ini memungkinkan bagi masyarakat, baik secara individu maupun dalam kelompok untuk ikut serta. promosi kuliner juga sebagai bentuk diplomasi publik yang bertujuan sebagai pendekatan sosial politik maupun ekonomi bahkan social dan budaya. Sebagai upaya mempererat hubungan dengan negara lain dalam mengatasi permasalahan maupun konflik antar negara .

Pada aspek informasi, pengaruh, dan keterlibatan. Hasil dari penelitian menunjukkan bahwa Kedutaan Besar Jepang di Indonesia menggunakan media sosial seperti facebook dalam mempromosikan kuliner hal ini merupakan cara yang efektif mengingat Indonesia merupakan salah satu pengguna terbesar media sosial di dunia, hal ini juga mampu memberikan pemahaman serta citra yang baik bagi Jepang oleh publik pengguna media sosial di Indonesia yang dilihat dari jumlah pengikut, suka, dan komentar yang positif pada berbagai postingan admin facebook kedutaan besar jepang di Indonesia. Pemerintah Jepang mengembangkan dan melaksanakan berbagai 
kegiatan diplomasi publik di Indonesia sebagai upaya untuk memperkuat hubungan jangka panjang bagi kedua Negara

Penelitian ini bersifat deskriptif kualitatif dengan subjek penelitian ialah media sosial Facebook Kedutaan Besar Jepang di Indonesia. Sedangkan teknik pengumpulan data dilakukan melalui wawancara, dan dokumentasi. Dalam penelitian ini yang menjadi informan yaitu admin Facebook Kedutaan Besar Jepang di Indonesia dan salah satu anggota Sekretariat Little Tokyo World Cosplay Summit Indonesia Kommitte. Adapun teknik analisa data yang digunakan dalam penelitian ini adalah analisis model interaktif yang berisi tahapan pengumpulan data, reduksi data, penyajian data, dan simpulan (Miles, Huberman, \& Saldana, 2014)

Hasil dari penelitian ini menunjukan bahwa era digitalisasi informasi menandai kondisi politik internasional pada konteks hubungan internasional. hal ini terkait pada situasi di mana melalui instrumen diplomasi aspek informasi dan teknologi memainkan peranan penting pada upaya pencapaian kepentingan nasional. Awalnya diplomasi antar aktor dalam politik internasional yang semula berfokus pada upaya pencapaian kepentingan nasional menggunakan jalur-jalur tradisional, seperti negosiasi formal antar perwakilan negara, tekanan ekonomi dan militer. Dan pada perkembangannya telah bergeser menjadi diplomasi yang berbasis internet di mana upaya pencapaian kepentingan nasional suatu negara tidak lagi dipengaruhi oleh kekuatan hard seperti militer dan ekonomi, namun bisa menggunakan media sosial.

Dalam penggunaannya media sosial adalah alat pendukung kegiatan diplomasi publik. Media sosial faceboo dan instagram di anggap mampu menjalin hubungan lebih luas yang di lihat dari 3 aspek yaitu dalam hal digital agenda setting, presence expansion, dan digital conversation generating.

Secara umum diplomasi publik Kedutaan Besar Jepang di Indonesia yaitu mengadakan acara pertukaran budaya dan olahraga serta pertukaran warga, melaksanakan promosi bahasa dan kebudayaan jepang (kerjasama dengan Japan Foundation), melaksanakan promosi pendidikan Jepang (beasiswa, dan lain-lain) dan pertukaran instansi pendidikan tinggi, mempublikasikan berbagai informasi diberbagai platform (website, media sosial, dan lain-lain), hubungan dengan pers (mengeluarkan pers release, dan lain-lain). ( Admin Facebook Kedutaan Besar Jepang di Indonesia 25 oktober 2019). Dalam hal penggunaan media sosial sebagai alat 
mendukung kegiatan diplomasi publik Kedutaan Besar Jepang menggunakan media sosial seperti facebook, dan Instagram.

Dalam Penyampaian informasi diplomasi publik digunakan untuk penyampaian komunikasi oleh aktor negara terhadap publik untuk mengelola hubungan baik dengan pihak lain atau dengan negara lain untuk menarik perhatian publik dari luar negaranya. Penyampaian informasi jika dilakukan dengan benar maka membawa keberhasilan bagi pihak yang menyampaikan informasi. Saat ini penyampaian informasi tidak mesti dilakukan dengan bertatap muka, tetapi di era modern sekarang ini panyampaian informasi melibatkan peran media sosial sebagai sarana informasi yang sangat mudah, sehingga saat ini pemerintah dalam suatu negara tertarik menggunakan media sosial sebagai sarana informasi untuk mempromosikan kegiatankegiatan maupun mempromosikan potensi terbaik dalam negaranya, salah satunya Kedutaan Besar Jepang di Indonesia yang aktif menggunakan media sosial sebagai sarana informasinya.

Tujuan atau keterlibatan hal ini membangun hubungan jangka panjang dan meningkatkan rasa kepercayaan dan pemahaman terhadap publik di negara lain. Untuk mempererat hubungan diplomasi tersebut, kedua negara harus mampu menciptakan kepercayaan terhadap negara tujuan untuk mencapai kepentingan nosional suatu negara. Salah satu upaya yang dilakukan Kedutaan Besar Jepang di Indonesia adalah selain promosi kuliner melalui media sosial juga mempromosikan kuliner Jepang diberbagai kesempatan seperti promosi kebudayaan atau pariwisata Jepang. Memperkenalkan kuliner khas jepang yang belum banyak diketahui dikalangan masyarakat indonesia melalui pegelaran kuliner Jepang dengan mengadirkan chef langsung dari Jepang harapannya agar hubungan kedua negara bisa terus diperkuat. Artinya tidak hanya urusan politik dan ekonomi tapi juga pertukaran budaya seperti kuliner. Hal ini dilihat dari banyaknya restoran Jepang yang menyediakan kuliner khas Jepang yang berkembang di Indonesia.

Saran yang dapat diberikan pada review yaitu selanjutnya peneliti mungkin dapat lebih melanjutkan penelitian mengenai hambatan-hambatan yang terjadi dalam Promosi Kuliner Jepang Melalui Media Social Sebagai Bentuk Diplomasi Publik, sehingga apa yang menjadi kendala dalam pelaksanaan diplomasi antar negara menjadi lebih mudah. 


\section{Promosi Pariwisata Melalui Digital Diplomacy : Upaya Internasionalisasi Parawisata Daerah}

Permasalahan yang diangkat dalam membahas jurnal ini yaitu, untuk terlibat dalam aktivitas internasional untuk mengembangkan potensi daerah yang dimiliki. Melalui diplomasi digital memudahkan pemerintah daerah untuk mempromosikan potensi yang dimiliki. Sehingga Pariwisata dikenal sebagai salah satu sektor yang dapat mengambil manfaat dari perkembangan teknologi informasi dan komunikasi (Cardoso, 2005). Dalam mendukung untuk mengatasi masalah maka Penelitian inibertujuan untuk mengetahui diplomasi digital pemerintah daerah Wakatobi dalam mempromosikan pariwisata daerah di dunia internasional.

Dalam jurnal ini menggunakan metode kualitatif dengan lokasi penelitian di kabupaten wakatobi. Sumber datayang di gunakan yaitu data primer dan sekunder yang di kumpulkan beberapa metode. Data primer dalam studi ini bersumber dari hasil wawancara, sedangkan data sekunder didapatkan dari website dan media sosial yang digunakan Dinas Pariwisata dan Ekonomi Kreatifpemerintah Kabupaten Wakatobi dalam mempromosikan pariwisata Wakatobi. ModelAnalysis Interactive dari Miles dan Huberman (1994) digunakan sebagai analisis data dalamstudi ini yang menggambarkan kegiatan analisis dalam beberapa tahapan pengumpulan data,reduksi data, penyajian data, dan penarikan kesimpulan atau verifikasi data.

Dari hasil penelitian diketauhi bahwa Website dinas pariwisata lahir dengan begitu banyak diversifikasi yang awalnya masih menggunakan wakatobi.info. Pada tahun 2016 itu kembali terjadi perubahan menjadi wakatobitourism.com yang bertahan sampai saat ini dan digunakan sebagai salah satu instrumen pelaksanaan $e$ diplomacy. Bahasa utama yang digunakan yaitu bahasa inggris yang mencakup seluruh pariwisata wakatobi yaitu dari akses ke Wakatobi, kegiatan-kegiatan wisata yang dilakukan di Wakatobi, akses keterangan destinasi pariwisata dan akses terkait akomodasi.

Dalam pelaksanaan promosi wisata daerah Dinas Pariwisata dan Ekonomi Kreatif Kabupaten Wakatobi menggunakan media TIK seperti pemanfaatan internet. Dalam konteks ini diplomasi digital mempromosikan penggunaan TIK untuk memenuhi 
kebijakan suatu daerah sebagai upaya untuk memberikan informasi tidak hanya dalam negeri tapi juga luar negeri. Selain itu diplomasi pemerintah daerah pemerintah Wakatobi juga dilakukan dengan mengikuti berbagai acara-acara internasional seperti pameran diberbagai negara. Dibandingmenggantikan upaya ini ini kemudian melengkapi diplomasi tradisional . Selan itu penggunaan media sosial juga menjadi alat bagi pemerintah daerah dalammempromosikan pariwisata daerah Wakatobi seperti penggunaan Facebook, Instagram danTwitter. Nama akun Facebook dan Instagram yaitu@visitwakatobi sedangkan untuk twitter dengan nama akun@tourismwakatobi. Media sosial ini dimanfaatkan oleh pemerintah daerah dan untuk memberikan informasi terkait kepariwisataan kepada wisatawan asing diberbagai belahan dunia. Brown (2008) berpendapat bahwa platform jejaring sosial global seperti Twitter dan Facebook memberikan banyak peluang untuk koneksi, dialog, dan interaksi antara pemerintah dan masyarakat asing.

Pemerintah Daerah Kabupaten Wakatobi melalui Dinas Pariwisata dan Ekonomi Kreatif Kabupaten Wakatobi dalam upayanya untuk mempromosikan pariwisata telah menggunakan media internet sebagai salah satu instrumen diplomasi digital. Usaha tersebut dapat dilihat dari terbentuknya dua website resmi, yaitu www.wakatobitourism.com sebagai website resmi dinas yang dikelola langsung instansi ini yang memuat informasi mengenaipariwisata Wakatobi sedangkan untuk infromasi kegiatan pemerintah tersedia dalam website pemerintah daerah yaitu www.wakatobikab.go.id. Melalui pembuatan situs web internet tersebut, kini pemerintah dinas pariwisata lebih relatif mudah dan cepat dalam mempromosikan pariwisata kabupaten Wakatobi ke dunia internasional. Hal ini kemudian selaras dengan studi Park \& Lim (2014) mengenai penggunaan jaringan informasi dan sosial media oleh pemerintah dalam mempromosikan produk dan nilai nasional melalui penggunaan teks dan gambar visual agar lebih terlibat dengan pengguna.

Saran yang dapat diberikan dalam review ini yaitu selanjutnya peneliti mungkin dapat melanjutkan penelitian mengenai mengatasi hambatan - hambatan yang terdapat dalam Promosi Pariwisata Melalui Digital Diplomacy : Upaya Internalisasi Parawisata Daerah. Bukan hanya mengenai promosi parawisata, masih banyak sektor lain yang dapat di jadikan dalam sebuah penelitian lebih lanjut. 


\section{References}

[1] Ramadhan, W. O. J., Sudirman, F. A., Saidin,S., \& Susilawati. F. T. (2020). Promosi Kuliner Jepang Melalui Media Sosial Sebagai Bentuk Diplomasi Publik : Study facebook kedutaan Besar Jepang Di Indonesia. Jurnal Ilmu Komunikasi UHO Dan Informasi. 5(1), 63-75

[2] Sudirman, F. A. Sarma, W. O. D., \& Susilawati, F. T. (2020). PROMOSI PARIWISATA MELALUI DIGITAL DIPLOMACY : UPAYA INTERNASIONALISASI PARIWISATA DAERAH. Jurnal Penelitian Kajian Ilmu Komunikasi dan Informasi. 5(3), 174-185 